Santa Clara University

Scholar Commons

Art and Art History

College of Arts \& Sciences

$1-1-2000$

\title{
Paris, Bibliotheque Nationale de France, Codex Grec 54: Modus Operandi of Scribes and Artists in a Palaiologan Gospel Book
}

Kathleen Maxwell

Santa Clara University, kmaxwell@scu.edu

Follow this and additional works at: http://scholarcommons.scu.edu/a_ah

Part of the Ancient, Medieval, Renaissance and Baroque Art and Architecture Commons, History of Religion Commons, and the Medieval History Commons

\section{Recommended Citation}

Maxwell, Kathleen. "Paris, Bibliothèque Nationale de France, Codex Grec 54: Modus Operandi of Scribes and Artists." Dumbarton Oaks Papers 54 (2000): 117-138. Dumbarton Oaks

Copyright (c) 2000, Dumbarton Oaks Research Library and Collection, Trustees for Harvard University. Originally published in Dumbarton Oaks Papers 54, edited by Alice-Mary Talbot.

This Book Chapter is brought to you for free and open access by the College of Arts \& Sciences at Scholar Commons. It has been accepted for inclusion in Art and Art History by an authorized administrator of Scholar Commons. For more information, please contact rscroggin@scu.edu. 
This is an extract from:

\section{Dumbarton Oaks Papers, No. 54}

Editor: Alice-Mary Talbot

Published by

Dumbarton Oaks Research Library and Collection

Washington, D.C.

Issue year 2000

(C) 2000 Dumbarton Oaks

Trustees for Harvard University

Washington, D.C.

Printed in the United States of America

www.doaks.org/etexts.html 


\title{
Paris, Bibliothèque Nationale de France, Codex Grec 54: Modus Operandi of Scribes and Artists in a Palaiologan Gospel Book
}

\author{
Kathleen MaXwell
}

$\mathrm{M}$ uch can be learned about the working methods of scribes and artists when they leave their product unfinished. ${ }^{1}$ This is true of the late thirteenth-century illustrated Gospel book, Paris, Bibliothèque Nationale de France, cod. gr. 54. It was intended to be a deluxe, bilingual (Greek and Latin) manuscript featuring full-page evangelist portraits and an extensive narrative cycle of some fifty-two miniatures. In the end, only about half of its Latin text and twenty-two narrative miniatures were actually completed. Five other miniatures remain unfinished, and space was reserved in the text for twentyfive additional miniatures that were never even begun. ${ }^{2}$ No ornamental headpieces were painted (although space was reserved for them by the scribe), and the Latin text lacks many initials. ${ }^{3}$ These unfinished elements offer insight into the working methods of Paris 54 's scribes and artists, and they allow us to recognize some degree of interaction between members of these two groups.

This article is derived in part from my dissertation, "Paris, Bibliothèque Nationale, Codex Grec 54: An Analysis of the Text and the Miniatures" (Ph.D. diss., University of Chicago, 1986). Professor Robert S. Nelson suggested that I research Paris 54 for his Byzantine manuscript illumination seminar during the winter quarter of 1978 and served as my dissertation advisor. I am happy to take this opportunity to thank Professor Nelson for the interest and support he has demonstrated over the years in my work on this topic. I also wish to thank Kathryn Wayne, and her predecessor, Ann Gilbert, art history librarians of the University of California at Berkeley, for the generous access accorded me to the art history seminar since 1982 when I moved to San Francisco. Thank you also to Dr. Alfred Büchler, Professor Christine Havice, and Professor Richard Rouse, who read various drafts of this manuscript. I have also benefitted from the comments of the anonymous readers for Dumbarton Oaks Papers to whom I am much indebted. Finally, very special thanks to my husband, Paul Missiroli Sullam, whom I met shortly after I began my study of Paris 54 and who has shown unconditional support for my work ever since.

${ }^{1}$ See J. Lowden, The Octateuchs: A Study in Byzantine Manuscript Illumination (University Park, Pa., 1992), 23-26, 64 (re: the Seraglio Octateuch); J. C. Anderson, "The Seraglio Octateuch and the Kokkinobaphos Master," DOP 36 (1982): 101.

${ }^{2}$ See the Appendix for a description of the contents of Paris 54.

${ }^{3}$ Neither the Greek nor Latin texts of any of the four Gospels ever received an opening decorated initial. Moreover, Luke's Gospel contains no titles for either the Greek or Latin texts, and John's Gospel has no title for its Latin text (see Figs. 1 and 17). 
Our understanding of the circumstances in which illustrated manuscripts of the early Palaiologan era were produced remains limited. There is no evidence of an imperial scriptorium, ${ }^{4}$ and the execution of text and miniatures is thought to have occurred in separate locales. ${ }^{5}$ Typically, the scribe appears to have been responsible for the basic design of the manuscript, including text format and decisions concerning the size and location of decoration and/or illustration. That is, he wrote the text, reserving space as appropriate for headpieces, illuminated initials, and illustrations. Once his task was accomplished, he presumably turned the completed text over to an artist (or a group of artists) for ornament and miniatures. However, even when significant numbers of manuscripts can be grouped together based on script, ornament, and/or illustration, they often reveal surprisingly complex relationships between scribes and artists that do not conform to any convenient definitions evoked by the term "atelier." 6

The results of my study of Paris 54 underscore the highly variable nature of the artist/scribe relationship. We shall see that the relative autonomy of the primary scribe responsible for the Greek text is upheld, but correspondences between anomalies in the Latin text and the miniatures of the narrative cycle indicate that some scribes and artists worked more intimately in the production of Paris 54 than appears to have been typical of Byzantine manuscripts of this or other periods. ${ }^{7}$ I will begin with a review of the literature related to Paris 54 and proceed gospel by gospel, analyzing texts and miniatures in an effort to determine how Paris 54 was produced.

${ }^{4}$ See H. Belting, Das illuminierte Buch in der spätbyzantinischen Gesellschaft (Heidelberg, 1970), 51-60.

${ }^{5}$ See H. Buchthal and H. Belting, Patronage in Thirteenth-Century Constantinople: An Atelier of Late Byzantine Book Illumination and Calligraphy, DOS 16 (Washington, D.C., 1978), 91-93. Robert S. Nelson writes that "a division of labor between the writing and decorating of a Greek manuscript appears to have long existed in Byzantium, and examples of the disassociation of script and decoration have been noted from the tenth to the fourteenth centuries." See further, R. Nelson, Theodore Hagiopetrites: A Late Byzantine Scribe and Illuminator (Vienna, 1991), $118 \mathrm{ff}$ and n. 23, for a helpful summary of these issues and related bibliography.

${ }^{6}$ Nelson writes: "Thus deluxe Greek manuscripts were produced by no single method, and varying combinations of individuals might collaborate on the three basic components, script, ornament, and figural miniatures." See further, Nelson, Theodore Hagiopetrites, 120. The difficulties encountered in trying to define how manuscripts were produced in the late 13th century are echoed in R. Nelson and J. Lowden, "The Palaeologina Group: Additional Manuscripts and New Questions,” DOP 45 (1991): 62-63 and 67-68. See also H. Buchthal, "Illuminations from an Early Palaeologan Scriptorium," JÖB 21 (1972): 48 ff; L. Brubaker, "Life Imitates Art: Writings on Byzantine Art History, 1991-1992," BMGS 17 (1993): 173-223; and esp. S. Dufrenne, "Problèmes des ateliers des miniaturistes byzantins," Akten, I/2: XVI Internationaler Byzantinistenkongress = JÖB 31.2 (1981): 445-70.

${ }^{7}$ Exceptions include an unusual example of close collaboration between a scribe and an illuminator in a Greek New Testament from the Escorial (cod. X.IV.17) noted by Buchthal: "They were members of a single team. There are comparatively few instances in Byzantine illumination where this point—a point which we take for granted in the Latin West-is so obvious." See H. Buchthal, "A Greek New Testament Manuscript in the Escorial Library: Its Miniatures and Its Binding," in Byzanz und der Westen: Studien zur Kunst des europäischen Mittelalters, ed. I. Hutter, SBWien, vol. 412 (Vienna, 1984), 92-93. Irmgard Hutter describes the differing relationship between art and text in Byzantium and the Latin West in "Decorative Systems in Byzantine Manuscripts, and the Scribe as Artist: Evidence from Manuscripts in Oxford," Word and Image 12.1 (1996): 4 and $18 \mathrm{n}$. 12 for further bibliography.

There are cases in Byzantine manuscripts where the scribe is also the illuminator and/or the artist, see Nelson, Theodore Hagiopetrites, esp. $116 \mathrm{ff}$; and K. Corrigan, "Constantine's Problems: The Making of the Heavenly Ladder of John Climacus, Vat. gr. 394,” Word and Image 12.1 (1996): 61-93, where she demonstrates that the scribe, Constantine, was also responsible for the miniatures. 


\section{Historiographical REVIEW}

Paris 54 attracted the attention of New Testament scholars almost a century before its citation in the publications of paleographers or art historians. ${ }^{8}$ Paris 54's bilingual text led many to propose that it was produced on Italian soil. ${ }^{9}$ This hypothesis attracted Gabriel Millet's opposition as early as 1916 and was opposed again in 1931 by Viktor Lazarev. ${ }^{10}$ It was not until 1929, when Henri Omont fully published Paris 54's illustrations, that the manuscript began to be consistently noted by art historians. ${ }^{11}$ In 1944 Kurt Weitzmann related the evangelist portraits of Paris 54 to those of four other Byzantine codices: Athos, Iviron 5; Athens, National Library, cod. 118; Princeton, University Library, MS Garrett 2 (olim Andreaskiti 753), and Philotheou 5. ${ }^{12}$ Iconographic parallels between some of these Byzantine portraits and several evangelists in the Wolfenbüttel Sketchbook, a Western product datable to the second quarter of the thirteenth century, as well as the presence of Latin scripts in some of the portraits of the Byzantine group, led Weitzmann to suggest that the latter must date from the first half of the thirteenth century, a period coinciding with the Latin Occupation of Constantinople (1204-61). ${ }^{13}$ He proposed further that these manuscripts were produced in Constantinople following tenth-century models and had been commissioned, or perhaps adjusted, for a Latin customer. ${ }^{14}$ Weitzmann was apparently unaware that a link had already been made between

${ }^{8}$ See, for example, Johan Jakob Wetstein, Novum Testamentum Graecum editionis receptae cum lectionibus varientibus Codicum MSS., Editionum aliarum, Versionum et Patrum, nec non commentario pleniore ex scriptoribus veteribus Hebraeis, Graecis et Latinis historiam et vim verborum illustrante, vol. 1, Continens Quattuor Evangelia (Amsterdam, 1751), 47, where he dates Paris 54 to the 14th century based on its Latin script.

${ }^{9}$ The following thought that Paris 54 was probably produced in Italy: J. P. P. Martin, Description technique des manuscrits grecs relatifs au Nouveau Testament conservés dans les bibliothèques de Paris (Paris, 1884), 29; N. V. Pokrovskij, Evangelie v pamjatnikach ikonografii preimuščestvenno vizantijskich i russkich (St. Petersburg, 1892), xx; A. Vaccari, "La Grecia nell'Italia meridionale," Orientalia Christiana 3.13 (1925): 273 ff (I thank Susan Pinto Madigan for this reference.); H. Gerstinger, Die griechische Buchmalerei (Vienna, 1926), 38; A. Grabar, La peinture religieuse en Bulgarie (Paris, 1928), 170; and H. Omont, Miniatures des plus anciens manuscrits grecs de la Bibliothèque nationale du VIe à XVIe siécle (Paris, 1929), 47 n. 1. J. J. Tikkanen, Studien über die Farbengebung in der mittelalterlichen Buchmalerei, Commentationes Humanarum Litterarum, Societas Scientiarum Fennica (Helsinki, 1933), 132 and 163, suggested that Paris 54 may have come from Italy.

${ }^{10} \mathrm{G}$. Millet, Recherches sur l'iconographie de l'Évangile aux XIVe, XVe et XVIe siècles (Paris, 1916), 646; V. Lazarev, “Duccio and Thirteenth Century Greek Icons," The Burlington Magazine 59 (1931): 159.

${ }^{11}$ Omont, Miniatures des plus anciens manuscrits grecs, pls. XC-XCVI.

${ }^{12}$ It has since been suggested that the texts of two of these manuscripts date from prior to the 13th century and that their current portraits were added during the Palaiologan period. Belting supports an early 12thcentury date for the text of Princeton, Garrett 2, while Prato has argued that the text of Athens 118 can be dated to the late 10th century on paleographical grounds. Prato also notes that both Paris 54's and Iviron 5's Greek texts betray their 13th-century date through the intrusion of numerous majuscule letters, especially epsilon and eta. See Belting, Das illuminierte Buch, 61; G. Prato, "Scritture librarie arcaizzanti della prima età dei Paleologi e loro modelli," Scritture e civiltà 3 (1979): 169 and pl. 5; and idem, "La produzione libraria in area greco-orientale nel periodo del regno latino de Costantinopoli (1204-1261)," Scritture e civiltà 5 (1981): 105-7.

${ }^{13}$ Few dated 13th-century manuscripts were known at the time Weitzmann was writing his article, see K. Weitzmann, "Constantinopolitan Book Illumination in the Period of the Latin Conquest," GBA 25 (1944): 193-214, reprinted in Studies in Classical and Byzantine Book Illumination, ed. H. L. Kessler (Chicago, 1971), $314 \mathrm{ff}$.

${ }^{14}$ Ibid., 200 f. Weitzmann was following Millet's lead here with regard to both Paris 54's date and locale. See Millet, Recherches sur l'iconographie de l'Évangile, 646. 
Paris 54 and a manuscript dated to 1298. In $1933 \mathrm{~J} . \mathrm{J}$. Tikkanen noted that two of the evangelist portraits of Paris 54 recur in the Smyrna Lectionary. ${ }^{15}$

In 1949 Lazarev reviewed Weitzmann's article and insisted that Weitzmann's whole group be assigned to the second half of the century on the basis of stylistic comparisons with such dated thirteenth-century manuscripts as London, British Library, Burney 20 (dated 1285). ${ }^{16}$ Less than a decade later, Otto Demus wrote his landmark article on the origins of the Palaiologan style and supported Lazarev's later date for most members of Weitzmann's manuscript group. He also cautioned that stylistic analysis of these portraits was extremely difficult, since many follow the style of their tenth-century models while others were executed in a wholly Palaiologan mode. Demus opted for a date in the 1260s for both Paris 54 and Iviron $5{ }^{17}$ These dates were revised just a few years later when Demus proposed a date within the rule of Michael VIII (1261-82) for Iviron 5. Demus contrasted its "painterly" style with the "cubist" and "extreme solution" of Paris 54, which he dated ca. 1285-89. ${ }^{18}$

A date for Paris 54 late in the thirteenth century was implied by Rudolph Naumann and Hans Belting in their study of the Euphemia Church in Constantinople, ${ }^{19}$ when they arrived at a date in the fourth quarter of the thirteenth century for the church's fresco cycle after comparing its ornament to that of many of the monuments discussed by Lazarev. $^{20}$

In his 1967 survey of Byzantine art, Lazarev devoted considerable attention to both Iviron 5 and Paris 54 and their respective dates. He dated Iviron 5 to the last third of the thirteenth century and Paris 54 to the last quarter of the thirteenth century. Lazarev thought that the former was a first-rate Constantinopolitan product and that Paris 54 was based on the same model but provincial in execution. He believed Paris 54 to be the product of a Macedonian master working for a high-ranking Crusader or Latin prelate. Lazarev also argued that Paris 54 was later in date because its style was more representative of mature Palaiologan trends than Iviron $5 .{ }^{21} \mathrm{~A}$ few years later, Belting dated Iviron 5 to the mid-thirteenth century and suggested that Paris 54 was about two decades later (ca. 1280). ${ }^{22}$

In 1975/76 an important contribution concerning the chronology of Weitzmann's

${ }^{15}$ See Tikkanen, Studien über die Farbengebung, 201 n. 1.

${ }^{16}$ See V. N. Lazarev, review of Weitzmann, "Constantinopolitan Book Illumination in the Period of the Latin Conquest," in VizVrem 2 (1949): 368 f (in Russian). Later, in an article supporting a date ca. 1285 for Leningrad 101, Lazarev again argued in favor of his later date for Weitzmann's group. Stylistic comparisons were also made with Jerusalem, Taphou 5, and with the Mokwi Gospels (dated 1300); see V. N. Lazarev, "Novyj pamiatnik konstantinopol'skoj miniiatiury XIII v.," VizVrem 5 (1952): 178-90.

${ }^{17}$ O. Demus, "Die Entstehung des Palaeologenstils in der Malerei," Berichte zum XI. Internationalen Byzantinisten-Kongress (Munich, 1958), 4.2:20.

${ }^{18}$ O. Demus, "The Style of the Kariye Djami and Its Place in the Development of Palaeologan Art," in The Kariye Djami, vol. 4, Studies in the Art of the Kariye Djami and Its Intellectual Background, ed. P. Underwood (Princeton, 1975), 145-46. (N.B.: Demus's manuscript was submitted in 1960.)

${ }^{19} \mathrm{R}$. Naumann and H. Belting, Die Euphemia-Kirche am Hippodrom zu Istanbul und ihre Fresken, IstForsch 25 (Berlin, 1966), 153-68.

${ }^{20}$ See above, note 16.

${ }^{21}$ V. Lazarev, Storia della pittura bizantina (Turin, 1967), 278-81.

${ }^{22}$ Belting, Das illuminierte Buch, 35 and 40 n. 134. 
group was made by Stella Papadaki-Oekland, when she republished photos of the Smyrna Lectionary (dated 1298). The Mark and John portraits of this manuscript are of the same type as their counterparts in Iviron 5 and Paris 54. If the Smyrna manuscript's portraits can also be assumed to date to $1298,{ }^{23}$ then Papadaki-Oekland has provided all the evidence necessary to push back, by perhaps as much as a decade, the date of some of the later members of Weitzmann's group. ${ }^{24}$ Papadaki-Oekland suggests that both Athens 118 and Iviron 5 should be dated before the Smyrna Lectionary, while Princeton, Garrett 2 and Philotheou 5 immediately post-date it. ${ }^{25}$ Unfortunately, Papadaki-Oekland was not aware that connections between the Smyrna Lectionary and members of Weitzmann's Constantinopolitan group had already been made by Tikkanen long before even Weitzmann's 1944 publication. ${ }^{26}$

Hugo Buchthal reassessed the Weitzmann group in his comprehensive study of the Wolfenbüttel Sketchbook. ${ }^{27} \mathrm{He}$ argued for dates as early as the 1250 s for the Athens Gospels and after 1300 for later manuscripts. On the basis of stylistic comparisons with the frescoes of Sopoćani, Iviron 5 was dated ca. 1265 and Paris 54 was assigned to the last quarter of the thirteenth century. As a result of this fifty-year span, Buchthal argued that these manuscripts should no longer be considered as a group:

They do not, in fact, form a real group; the miniatures are not homogeneous enough to be assigned to a single scriptorium or school of illumination. The manuscripts present a rather diversified picture, in which it is only the constant repetition of certain clearly recognizable types which reappear in various combinations, that gives the impression of a fairly uniform style. In other words, the miniatures are transmitting the style of their iconographical models, even more than in earlier periods of Byzantine art. And when the model is somewhat antiquated and the development extends over several decades, the survival of isolated figure types should not be taken for real continuity. ${ }^{28}$

Buchthal only acknowledges the possibility of a one-to-one copy relationship between Iviron 5 and Paris 54 and isolates the two manuscripts as a distinct subgroup. ${ }^{29}$

With this much effort to place Paris 54 in the third or even fourth quarter of the thirteenth century, it is surprising to note that Weitzmann's mid-thirteenth-century date

${ }^{23}$ The manuscript was apparently destroyed in the early $1920 \mathrm{~s}$.

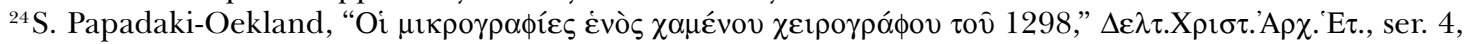
8 (1975-76): 29-54 (in Greek with English summary). More recently, Nelson and Lowden, "The Palaeologina Group," 62, have linked the scribe of the Smyrna Lectionary to manuscripts associated with the "Atelier of the Palaeologina." For the latter, see Buchthal and Belting, Patronage in Thirteenth-Century Constantinople.

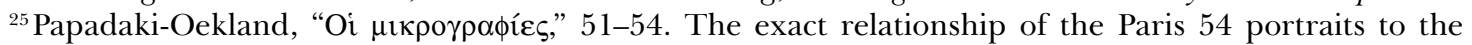
Smyrna portraits is not discussed in the English summary.

${ }^{26}$ Ibid. In her English summary, Papadaki-Oekland writes that the Smyrna manuscript has not been mentioned in the literature since 1909. No one concerned with the issues of "Weitzmann's Constantinopolitan manuscript group" seems to have been aware of Tikkanen's contribution-least of all Weitzmann. See Tikkanen, Studien über die Farbengebung, 201 n. 1.

${ }^{27}$ H. Buchthal, The "Musterbuch" of Wolfenbüttel, ByzVindo 12 (Vienna, 1979), 45-46. See now also, I. Spatharakis, The Left-handed Evangelist: A Contribution to Palaeologan Iconography (London, 1988). The Wolfenbüttel Sketchbook plays a central role in Spatharakis' discussion.

${ }^{28}$ Buchthal, The "Musterbuch" of Wolfenbüttel, 45-46.

${ }^{29}$ Ibid., 47. A few years later, Nelson pushed back the date of Iviron 5 to ca. 1285 on the basis of comparisons with London, British Library, Burney 20 (dated 1285). See R. S. Nelson, "Paris, Gr. 117 and the Beginnings of Palaeologan Illumination," WJKg 37 (1984): 18. 
is upheld in the Louvre catalogue that accompanied the 1992 exhibition Byzance: l'art byzantin dans les collections publiques françaises. ${ }^{30}$

As the foregoing demonstrates, a definitive chronology for thirteenth-century Byzantine illustrated manuscripts remains elusive. However, great strides have been made in the last twenty-five years, and much of that progress is built upon the foundations provided by Lazarev in his Russian publications of more than a half century ago.

Paris 54 remains something of an anomaly. Extensively illustrated Gospel books are rare in the Palaiologan period. As has been pointed out by others, it appears that monumental painting became the preferred venue for extensive narrative cycles in this period. ${ }^{31}$ However, as we shall see in the next section, there are many aspects of Paris 54 that contribute to its singular status, above and beyond its narrative cycle.

\section{DESCRIPTION}

Paris 54 is a generously proportioned manuscript ( 335 by $250 \mathrm{~mm}$ ), with a handsome double-column layout (Figs. 1 and 7), ${ }^{32}$ a format dictated by its bilingual text. ${ }^{33}$ The Greek text takes precedence over the Latin through its location in the left column. Paris 54 is bilingual in another aspect as well. It contains two different sets of quire signatures. ${ }^{34}$ Greek quire signatures are found through almost two-thirds of the manuscript (through quire 22; see Appendix). Armenian quire signatures appear throughout the entire manuscript (i.e., through quire 35). ${ }^{35}$ The Armenian quire signatures in Paris 54 are likely to

\footnotetext{
${ }^{30}$ Musée du Louvre, 3 November 1992-1 February 1993 (Paris, 1992), 450 (with color illustration of the Evangelist Mark). The bibliography in Paris 54's catalogue entry does not cite, however, any more recent publication by an art historian than the 1971 reprint of Weitzmann's "Constantinopolitan Book Illumination" (above, note 13).

${ }^{31}$ See Nelson and Lowden, "The Palaeologina Group," 64.

${ }^{32}$ The two texts were not allotted equal space; the Greek text column averages $9.3 \mathrm{~cm}$ in width and always continues through the first part of the space between the two text columns, which itself measures $1.4 \mathrm{~cm}$ in width (the distance from $b$ to $c$ in Fig. 7). The Latin text, on the other hand, averages only $7 \mathrm{~cm}$ in width.

${ }^{33}$ See B. M. Metzger, Manuscripts of the Greek Bible: An Introduction to Greek Paleography (New York, 1981), 56 , for a list of bilingual New Testament manuscripts. However, a more fruitful comparison, from a paleographical standpoint, is provided by the bilingual (Greek and Latin) Hamilton Psalter. See C. Havice, "The Marginal Miniatures in the Hamilton Psalter (Kupferstichkabinett 78.A.9)," JbBM 26 (1984): 79-142.

${ }^{34}$ For more information on quires, see E. Gamillscheg and R. Browning, "Quire," ODB 3:1767-68.

${ }^{35}$ C. R. Gregory, Textkritik des Neuen Testaments (Leipzig, 1909), 1:132, writes that the gatherings were first numbered in Greek and then in Armenian. This is unlikely, however, since, unlike the Greek quire signatures, the Armenian quire signatures extend throughout the entire manuscript. Gregory also wrote: "I have no doubt that it was at least in part the work of an Armenian; there are Armenian as well as Greek numbers for quires." Idem, Canon and Text of the New Testament (New York, 1907), 372. Other manuscripts that feature Armenian quire signatures include Brescia, A. VI.26, a Greek Gospel book whose evangelist portraits were repainted by an Armenian artist from the Crimea in the 14th century. See R. S. Nelson, The Iconography of Preface and Miniature in the Byzantine Gospel Book (New York, 1980), 42; K. Maxwell, "Armenian Additions to a Greek Gospelbook: Brescia, Biblioteca Civica Queriniana A. VI.26," REArm 25 (1994-95): 337-52; and H. Buschhausen and H. Buschhausen, "Die Halbinsel Krim, ein wenig beachtetes Zentrum der byzantinischen Buchmalerei im 14. Jahrhundert," Byzantine East, Latin West. Art-Historical Studies in Honor of Kurt Weitzmann, ed. C. Moss and K. Kiefer (Princeton, 1995), 339-43.

In addition, Millet noted long ago that Florence, Laurentian Library, Plut. VI. 23 was paginated in Armenian, presumably when an Armenian copy of it (Erevan, Matenadaran 7651) was produced in the 13th century. See Millet, Recherches sur l'iconographie de l'Évangile, 569. See also S. Der Nersessian, Miniature Painting
} 
date from the manuscript's production, since they share the somewhat unusual red ink color of the Greek quire signatures and the running text. Moreover, brief notations in Armenian are also found in the lower margins of folios 53r-79v. ${ }^{36}$ Paris 54 's quires are also unusual in that each contains ten folios rather than eight, as was the rule in Greek manuscripts. ${ }^{37}$

There is yet another aspect of Paris 54 that distinguishes it from virtually every other Byzantine manuscript: its ink is color coded according to the speaker in the text. ${ }^{38}$ Bright red ink was used for the simple narrative text, while a darker red or crimson ink was reserved for Jesus' words, the genealogy of Christ, and the words of the angels. Old Testament passages, the words of the disciples, Zachariah, Mary, Elizabeth, Simeon, and John the Baptist are in blue, while dark brown ink was used for the speech of the Pharisees, people from the crowd, Judas Ischariot, the Centurion, the devil, shepherds, and the scribes. ${ }^{39}$ The Greek text, written in a fine archaizing hand based on the eleventhcentury pearl script, is particularly impressive in appearance. ${ }^{40}$

in the Armenian Kingdom of Cilicia from the Twelfth to the Fourteenth Century, DOS 31 (Washington, D.C., 1993), 1:173 f, where an instruction to the scribe in Armenian on fol. 27v plot. VI. 23 is also noted. Finally, Francis Wormald noted the presence of Armenian quire signatures in a 12th-century Latin Crusader manuscript known as the Missal of the Church of the Holy Sepulchre (Paris, Bibliothèque nationale, cod. lat. 12056). He concluded that its scribe "was an Armenian who could write Latin." See H. Buchthal, Miniature Painting in the Latin Kingdom of Jerusalem, with paleographical and liturgical chapters by F. Wormald (Oxford, 1957), 135.

${ }^{36} \mathrm{I}$ have not succeeded in translating these notations. They are comprised primarily of a few indecipherable letters.

${ }^{37}$ Quinions are not typical of Armenian manuscripts either, as they also usually feature eight folios per quire. However, quinions (i.e., gatherings containing ten folios) were apparently typical in late antiquity and both the Rossano Codex and the Vienna Dioscurides feature quires made up of quinions. See G. Cavallo, G. Gribomont, and W. C. Loerke, Codex Purpureus Rossanensis, vol. 1, Commentarium, Codices Selecti, facs. 81 (Rome-Graz, 1987), 24. C. De Hamel, Scribes and Illuminators (Toronto-Buffalo, 1992), 18, writes that gatherings of ten leaves were also common in early Irish manuscripts and 15th-century Italian books. See ibid., 20, for the difficulties in constructing a quire of ten leaves relative to that of eight leaves.

${ }^{38}$ Gregory, Canon and Text, 372, dubbed Paris 54 the "rainbow manuscript." The only other Greek manuscript that I have encountered that offers a comparable effect is Oxford, Bodleian Library, Lincoln MS gr. 35 where on fols. $14 \mathrm{r}$ and $15 \mathrm{v}$ (only) the text is varied in blue, gold, and red. See A. Cutler and P. Magdalino, "Some Precisions on the Lincoln College Typikon," CahArch 27 (1978): 179-98; and I. Spatharakis, The Portrait in Byzantine Illuminated Manuscripts (Leiden, 1976), 190-207. F. Mütherich and J. E. Gaehde, Carolingian Painting (New York, 1976), 27, no. XVI, note that the first three pages of the sacramentary fragment from Metz (ca. 870) "are written in alternating lines of gold, green, and red capital letters on blank parchment." See also the facsimile Sakramentar von Metz, Ms. Lat. 1141, Bibliothèque Nationale, Paris, intro. F. Mütherich, 2 vols. (Graz, 1972). Nelson indicates that varied ink colors are also a characteristic of Gothic manuscripts: see Iconography of Preface and Miniature in the Byzantine Gospel Book, 42. An example of the discriminating use of varied ink colors to enrich the effect of the script is also seen in the Armenian realm. The text on the initial page of each gospel of the Glajor Gospels at the University of California at Los Angeles is written in splendid zoomorphic initials. These are followed in Matthew by several folios of gold script and in Mark, Luke, and John by two pages of red, black, and blue ink, respectively. See T. F. Mathews and A. K. Sanjian, Armenian Gospel Iconography: The Tradition of the Glajor Gospels, DOS 29 (Washington, D.C., 1991).

${ }^{39}$ That is, dark brown ink was used by mere humans, both of a positive and negative disposition towards Christ. Gregory, Canon and Text, 373, was the first to describe correctly the hierarchy of ink color in Paris 54.

${ }^{40}$ Pearl script is extremely regular and legible. See further Prato, "Scritture librarie arcaizzanti," 151-91. See also H. Hunger, "Archaisierende Minuskel und Gebrauchsschrift zur Blütezeit der Fettaugenmode: Der Schreiber des Cod. Vindob. Theol. gr. 303," in La Paléographie grecque et byzantine, Colloques Internationaux du Centre National de la Recherche Scientifique 559 (Paris, 1977), 283-90, esp. 285 f. 


\section{MATTHEW (FOLS. 11R-109V)}

Text

An analysis of the Greek text of Matthew suggests that the use of blue ink, at least, may have been an afterthought. Matthew's text begins with Christ's genealogy and was executed in the rarer crimson ink. Following the genealogy (Matt. 1:17), the text reverts to the bright red of the running text. ${ }^{41}$ The first instance of blue ink, on folio 13r (Matt. $1: 20)$, is superimposed directly over the bright red ink of the running text. For the next six folios, every example of blue ink was written over an erasure of red ink (e.g., Fig. 3). Subsequent appearances of blue ink in the Greek text show no trace of erasure beneath them. ${ }^{42}$ Therefore, the use of blue ink appears to have been conceived, and perfected, after the Greek text was initiated. Since the erasures occur only in the Greek text, I conclude that the Greek text was written in large part, if not in total, before the Latin text was begun. ${ }^{43}$

Several scribes executed the Latin text of the Gospel of Matthew, and they were careful to maintain absolute color symmetry with the Greek text. ${ }^{44}$ Undoubtedly, this symmetry was motivated by aesthetic aims. It was also necessary that both texts break for the narrative miniature at the same point, since the miniature extends across both text columns (Fig. 2).$^{45}$ As a result, an almost line-for-line color parallelism was attained throughout the text of Matthew. The scribal machinations through which this symmetry was achieved are of some interest.

If, for example, the scribe was not able to stretch the Latin text to fill the requisite number of lines (this having been determined by the Greek version on the left), he might then repeat regular minims ( $\mathrm{mmmmmmmm}$ ) to avoid leaving a gap. This horror vacui mentality is best illustrated, perhaps, on folio 16v (Fig. 3), where these minims continue for five and one-half lines in red ink in order to keep the following passage in blue ink parallel with the Greek text. The last four lines of folio 86r (Fig. 4) exhibit the same repetition of minims, but here they are randomly grouped to resemble words more closely (mmmmmmm mmm mmmm $\mathrm{mm} \mathrm{mmmm}$ ). Folio $16 \mathrm{r}$ offers an example of a more decorative means of maintaining color parallelism. Here, a series of flourishes

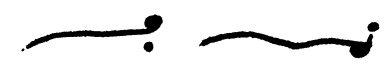

on lines 15-17 (Fig. 5) accomplishes the same result. Other text-stretching techniques include the repetition of the final words in a verse (e.g., ieiunantes, fol. 25v), the writing out of a word followed by its abbreviation (e.g., loquamini, fol. 38v; hominibus, fol. 39r), or even the repetition of an entire verse. Matthew 9:11, for example, was repeated at the

\footnotetext{
${ }^{41}$ Most Byzantine manuscripts are written in brown or black ink. However, Metzger writes that "whole manuscripts were sometimes written with red ink." See further, idem, Manuscripts of the Greek Bible, 17.

${ }^{42}$ Gregory, Textkritik, 1:132, also noted these erasures.

${ }^{43}$ These observations do not suggest a copy relationship with another manuscript (at least regarding this aspect of the text); in any event, there are no surviving manuscripts to support this assumption.

${ }^{44}$ I wish to thank Albert Derolez, Distinguished Visiting Professor, University of California, Berkeley, fall 1985, for reviewing a microfilm of Paris 54 with me and for very generously sharing his observations on its Latin script.

${ }^{45}$ See Lowden, Octateuchs, 70, where he demonstrates the importance of the correct location of the illustration vis-à-vis the text in his analysis of Vat. gr. 747.
} 
top of folio $34 \mathrm{v}$ to maintain color harmony with the Greek text, even though this verse had already been written at the bottom of folio $34 \mathrm{r}^{46}$

Far more frequently encountered than such text-stretching devices, however, is the resort to abbreviation, crowding, and awkward spacing to fit the Latin text in a space predetermined by the Greek. Obvious examples of this are seen on folios 22v (Fig. 6) and $35 \mathrm{r}$, but many more could be cited. This problem was certainly exacerbated by the unequal amount of space allotted to the Latin text columns (see Fig. 7).

\section{Narrative Miniatures}

Matthew's Gospel contains twelve narrative miniatures in addition to a full-page portrait of the evangelist inserted on a separate folio. All of these miniatures were completed by one of two artists, whom I have dubbed Artist A and Artist B. ${ }^{47}$

The evidence derived from Matthew's Gospel allows only limited conclusions concerning the production of this manuscript. Based on the evidence of the initial blue ink passages in the Greek text, however, we can deduce that Matthew's Greek text was completed before its Latin counterpart. We do not know, however, when the miniatures were executed. An analysis of the next three gospels indicates that, there, the miniatures were completed at the same time as, or even before the Latin text. ${ }^{48}$

$$
\text { MARK (FOLS. 111R-171V) }
$$

Text

The Greek text of Paris 54 was written in the varied ink colors throughout all four Gospels, but this practice was maintained in the Latin text only through the first thirty folios of Mark (up to fol. 142r). ${ }^{49}$ In fact, already by the end of the first quire of Mark, the color correspondence begins to break down. ${ }^{50}$ On folio $121 \mathrm{r}$ in the Latin text (Fig. 8), the top half of the page and two lines at the bottom have been written by a different hand from those seen thus far in the Latin text of Paris 54. Moreover, these passages, which should have been written in the rarer crimson ink, were instead written in black ink. The central portion of the folio was executed in bright red and dark brown inks, and in both cases the colors correspond appropriately, and the script is in the style of the Latin scribe. The new scribe's handiwork can also be identified on folio 122v, and here again passages that should have been written in crimson were incorrectly executed in the black ink.

\footnotetext{
${ }^{46}$ The repetition of biblical passages in order to synchronize with extensive catenae is also noted by Lowden with regard to Vat. gr. 747. See ibid., 11-12.

${ }^{47}$ Paris 54's narrative cycle will be discussed in more detail in a future publication.

${ }^{48}$ While Matthew's Gospel is the most complete in Paris 54, it still lacks the headpiece and the initials at the beginning of the Greek and Latin texts, as well as numerous initials within the Latin text.

${ }^{49} \mathrm{An}$ exception to this is on fol. 105r, where the complete page in Greek is written in bright red ink, but in the Latin text column one verse (Matt. 27:37: "This is Jesus the King of the Jews") is written in blue ink. Alfred Büchler alerted me to its significance as this is the inscription written over the cross in the Latin West. In contemporary Byzantine crosses, the inscription reads "King of Glory." See further, A. Büchler, "King of Glory and King of the Jews: The Titulus of the Cross in the Christian East," BSCAbstr 16 (1990): 68-69.

${ }^{50}$ That is, on the last folio (fol. 121r) of quire 11 (the first quire of Mark), which corresponds to Mark 3:27. See Appendix.
} 
The problems with the crimson passages in the Latin text continue intermittently through the third quire of Mark (fols. 132r-141v). On those folios that did not require the use of crimson ink, there is no evidence of the new scribe ${ }^{51}$ except on folio $142 \mathrm{r}$ (i.e., the beginning of quire 14), where the Latin text is executed wholly in black ink by the new Latin scribe (Fig. 9). The Latin text continues in this fashion until it terminates on folio 150 .

The problems encountered in the Latin text on folios 121-133 are so consistent as to clarify the manner in which the text was executed. The Greek text was completed first in the polychromatic ink colors. Then the Latin text was filled in but not from beginning to end. Instead, passages requiring the same color were completed at the same time over a number of folios. In the folios where there are problems with the crimson ink passages, the blue and dark brown passages appear to have been completed before the rarer crimson passages. The original scribe responsible for the Latin text apparently never had the opportunity to finish the crimson passages. It is difficult to gauge how much time may have elapsed before the new scribe began to finish those passages using the inappropriate black ink.

\section{Miniatures}

The scribe responsible for the Greek text reserved space for nine text miniatures throughout the Gospel of Mark. The first four miniatures were completed; the last five were not even begun. The four completed miniatures are by Artist B and occur in the first two quires. ${ }^{52}$ The first empty frame reserved for an uninitiated miniature is found at the beginning of the fourth quire of Mark, on folio 142r, which coincides with the beginning of major anomalies in the Latin text of Mark (Fig. 9). ${ }^{53}$ It is at folio 142r that the Latin text is, for the first time, executed by the new hand exclusively in black ink. On folio 150v, the Latin text stops, not to be resumed again until the Gospel of John. ${ }^{54}$

The evidence concerning the modus operandi of the scribes and artists working on the Gospel of Mark re-confirms that the Greek text was completed before the Latin. Here, however, we learn also that the miniatures were executed at the same time as the Latin text. Anomalies in Mark's unfinished Latin text coincide with the interruption of the

\footnotetext{
${ }^{51}$ On fols. $121 \mathrm{v}, 122 \mathrm{r}$ and $122 \mathrm{v}, 123 \mathrm{r}$ and $123 \mathrm{v}$, and $124 \mathrm{r}$ the passages in the Latin text that should have been written in crimson are also in black and by the new hand. On fols. $124 \mathrm{v}$ and $125 \mathrm{r}$, most of the Latin text is written in the original hand, but these are examples, too, of places where very little crimson ink was required. The problems with the crimson passages in the Latin text continue through fol. 129v. On these folios almost every example of black ink was written by the new scribe and should have been in crimson. Fols. 130r, 131r, 132v, 133v, and 134r are wholly by the first scribe. This is logical, in that none of the passages on these pages called for the use of crimson, whereas both fols. 132r and 133r have examples of black ink by the new hand where crimson-colored ink should have been used. The crimson passages on fols. $134 \mathrm{v}-140 \mathrm{v}$ appear to have been executed in the appropriate color and by the first hand. The only exception is on fol. 138r and verso; there in the Latin text, the script that should have been crimson, was written in a new blue-grey color and seems to be the work of the new hand.

${ }^{52}$ They are located in both quires on the versos of the third and fourth folios (fols. $114 \mathrm{v}, 115 \mathrm{v}, 124 \mathrm{v}$, and 125v).

${ }^{53}$ Spaces reserved for uninitiated miniatures in Mark are found on fols. 142r, 162v, 166r, 167v, and 168v. Significant blank spaces extending across both text columns or empty red frames indicate that a miniature was intended but never executed.

${ }^{54}$ With the exception of one brief passage on fol. 194r.
} 
miniature cycle. This raises the possibility, at least, that one of the Latin text scribes and Artist B were the same individual..$^{55}$ While this issue will not be pursued in the present paper, a close collaboration is suggested between Artist B and the Latin scribes at work before the final Latin hand appears.

LUKE (FOLS. 173R-276V)

Text

The Greek text of Luke is complete, but now the Latin text column is blank. However, examination of the miniatures of Luke's Gospel offers more detail about the ways in which scribes and artists created Paris 54.

\section{Miniatures}

Luke's Gospel was scheduled to receive twenty miniatures (see Appendix). ${ }^{56}$ Only five were completed, five remain unfinished, and ten were never begun. These miniatures were executed by a new artist, Artist $\mathrm{C}$, whose hand is not detected in the miniatures of Matthew and Mark. ${ }^{57}$ Thus, although no progress was made on the Latin text in Luke, the execution of the narrative miniatures was well underway.

Codicological examination of Luke's narrative cycle reveals certain trends. Three miniatures were scheduled for the first quire of Luke (Fig. 10). The first miniature, the Annunciation (fol. 176r), was completed, but the other two-the Visitation (fol. 177v; Fig. 11) and the Presentation (fol. 182r; Fig. 12)-were left unfinished. Three miniatures were also intended for the second quire (Fig. 13). Here also the first miniature the Baptism (fol. 186v), was completed, while the second miniature, the Miraculous Draught of Fishes (fol. 191v), which is located on the same bifolio, was not even begun. This is less surprising than might first appear. Although the Baptism and the Miraculous Draught of Fishes are both located on the versos of their respective folios, they are, in fact, located on opposite sides of the bifolio that they share (see Appendix).$^{58}$ The third miniature, the Cure of the Paralytic (fol. 193v), located on the last folio of the quire, was completed.

The third quire in Luke contains two miniatures (Fig. 14). The first, the Parable of the Widow of Naim (fol. 201r), was completed, while the second, the Anointing of Christ

\footnotetext{
${ }^{55}$ See Hutter, "Decorative Systems in Byzantine Manuscripts," 15; and Corrigan, "Constantine's Problems."

${ }^{56}$ The uninitiated miniature at the bottom of fol. $247 \mathrm{r}$ in Paris 54 may represent a scribal error. The red frame measures only $5.8 \times 16.9 \mathrm{~cm}$. The scribe has reserved another space at the top of the very next folio and its dimensions are more in keeping with the other narrative miniatures in Paris 54. Thus, there is the possibility that the Greek scribe intended to go back and erase the red frame on the bottom of fol. 247r but never got around to doing it.

${ }^{57}$ See above, note 47.

${ }^{58} \mathrm{~A}$ similar situation exists with regard to several miniatures in Matthew's text. The Denial of Peter and the Holy Women at the Sepulchre share the same bifolio and are located on the rectos of their respective folios. The same is true of the Remorse of Peter and the Descent from the Cross. The miniatures in both cases have distinctly different color schemes. In fact, the Denial and Remorse miniatures are very similar in coloration and style, as are the miniatures of the Descent and the Holy Women at the Sepulchre. This makes perfect sense given their respective themes and environments. It also makes sense from a codicological view, since, once again, even though both sets of miniatures are located on the rectos of their respective folios, they are not located on the same side of the bifolio they share.
} 
(fol. 203v), is the most advanced of the unfinished miniatures (Fig. 15). Two miniatures are also found in the fourth quire (Fig. 16). The first, Christ Asleep in the Boat (fol. 207r), remains unfinished, while the second, the Transfiguration (fol. 213r), is complete. No miniatures were scheduled for Luke's fifth quire. The Cure of the Man with Dropsy (fol. 233v) is the only miniature in the sixth quire of Luke; it is located on the last folio of the quire and was never finished. The remaining nine miniatures planned for Luke are distributed among the next five quires. None of these was ever begun. ${ }^{59}$

The pattern of completed and uninitiated miniatures in Mark, ${ }^{60}$ taken in conjunction with the location of unfinished miniatures in Luke, suggests that an artist did not complete one miniature at a time, or even the miniatures of one quire at a time. Instead, he worked on a number of miniatures at the beginning of each Gospel, and these might be dispersed over as many as a half dozen quires. ${ }^{61}$

One might assume, because the Greek text of Luke is complete and the Latin text blank, that no further evidence can be gleaned associating anomalies in the text with those in the narrative miniatures. In truth, however, surprising parallels can be demonstrated. Beginning with the seventh quire of Luke (quire 23; fols. 234r-243v) a number of anomalies of all types appear. Up until this point (i.e., through the sixth quire of Luke), both finished and unfinished miniatures occur (with only one example of an uninitiated miniature on fol. 191v; see Appendix). However, beginning with the seventh quire and for the remainder of Luke, only uninitiated miniatures are found. It is at the seventh quire that the Greek quire signatures suddenly disappear and are never resumed. (The Armenian quire signatures continue without interruption.) A different ruling system is also initiated at this point. ${ }^{62}$ And, it is with this quire that the parchment suddenly becomes thinner and more transparent. Moreover, the Greek script now looks different, perhaps suggesting the first appearance of a second Greek scribe. ${ }^{63}$ Finally, the canon

${ }^{59}$ The tenth quire of Luke is the penultimate quire of his Gospel. See Appendix.

${ }^{60}$ The four completed miniatures in Mark are found in the first two quires. See notes 52 and 53 above.

${ }^{61}$ Der Nersessian, Miniature Painting in the Armenian Kingdom of Cilicia, 169, arrived at similar conclusions in her study of Erevan, Matenadaran 7651. She notes that in the original 13th-century campaign of work on this manuscript "the work was carried on more or less simultaneously in all four gospels, but in none of them was it completed." Sargis Pidsak completed the unfinished miniatures of this manuscript in the next century, and with one exception the miniatures attributed to him are located in later quires of each gospel.

${ }^{62}$ Inconsistencies in the lineation can be seen beginning on fol. 234 and continuing through approximately fol. 290. At fol. 234, the left margin is not easily verified (compare $a$ in Fig. 7); the far right column $e$ has been frequently omitted, and the width of the space between the two text columns (the space between $b$ and $c$ ) is increased by $0.4 \mathrm{~cm}$. The upper and lower margins also differ, measuring 4.1 and $7.1 \mathrm{~cm}$, respectively. Fol. 243, which is the same bifolium as fol. 234, is even more puzzling, in that no lines can be distinguished at all. On fol. 235, $e$ is missing and no horizontals (including $f$ and $g$ ) are visible. The character of the space between the two text columns also differs considerably, in that it now contains four lines-two narrowly spaced, double lines delineate a wider intercolumniation. Fol. 235's counterpart, fol. 242, is identical. Fol. 236 is similar to fol. 234, while its counterpart, fol. 241, has very unevenly defined horizontals and no discernible vertical lines. Fol. 237 contains the newly defined space between the two text columns of fol. 235 and lacks $e$. The horizontals of fol. 237 have been drawn beyond $d$ in an uncharacteristically sloppy manner. At the beginning of the next quire, on fol. 244, the newly defined space between the two text columns is continued and the right margin, $e$, has been reinstated. The next forty-five or so folios continue in this vein and are distinguished by their careless ruling or by the fact that it is almost impossible to distinguish horizontals or verticals or both types of lines at any given time.

${ }^{63}$ The Greek text does continue in the polychromatic colors, however, suggesting that if this is a new scribe, little time elapsed between his work and that of the first Greek scribe. 
numbers beginning on folio $235 \mathrm{r}$ are inexplicably shifted to the right side of the column for the folio rectos only.

JOHN (FOLS. 278V-361V)

Text

The Greek text of John is fully executed in the four different ink colors (Fig. 17). The Latin text is also partially complete ${ }^{64}$ now in yet another (untrained?) hand that cannot compete with the beautiful script of the Greek text. The Latin scribe writes in dark brown ink only and does not justify the right margin.

\section{Miniatures}

John's miniature cycle seems, at first glance, to run counter to the pattern encountered in Mark and Luke. John's Gospel was scheduled to receive eleven narrative scenes, of which only one was executed. This single painted miniature, however, is not the first narrative miniature, as one would expect; rather, it is the third in the sequence. Closer scrutiny reveals, however, that the first two miniatures planned for John (and, of course, the evangelist portrait) are located in quire 27 (Fig. 18; see Appendix), the quire in which Luke's Gospel ends and John's Gospel begins. ${ }^{65}$ The evangelist portrait, an insert, is complete, but the two miniatures were not executed. Thus, the only executed miniature in John, Christ and the Samaritan Woman at the Well (fol. 289r), is the first miniature of the succeeding quire (fols. 285-294), that is, the first quire devoted exclusively to John's text.

\section{The Unfinished Miniatures: Technical Considerations}

The five unfinished miniatures of Luke allow us to reconstruct the means by which an artist painted them. ${ }^{66}$ They are listed below, not in the order they are encountered in the text, but in descending degree of completion:

Christ Asleep in the Boat, folio 207r

Presentation, folio 182r (Fig. 12)

\footnotetext{
${ }^{64}$ The Latin text stops permanently at fol. 329r.

${ }^{65}$ This is unusual, according to Nelson. Most scribes would begin a new quire with the start of each Gospel. See R. Nelson, "Theoktistos and Associates in Twelfth-Century Constantinople: An Illustrated New Testament of A.D. 1133," J. Paul Getty Museum Journal 15 (1987): 58 and n. 30. In Carr's discussion of the manuscripts of the decorative style, of which sixty are Tetraevangelia, she notes that the "quires are modified to permit the opening of major text divisions on new gatherings." See A. Weyl Carr, Byzantine Illumination, 1150-1250: The Study of a Provincial Tradition, ed. O. Grabar and H. L. Kessler, Studies in Medieval Manuscript Illumination 1 (Chicago, 1987), 2.

${ }^{66}$ These miniatures have fascinated scholars ever since they were first mentioned by Silvestre in his 1841 publication, Paléographie Universelle (no pagination). Some scholars actually prefer the drawings to the completed miniatures in Paris 54. H. R. Willoughby, The Four Gospels of Karahissar, vol. 2, The Cycle of Text Illustrations (Chicago, 1936), 91, wrote, "Practiced students nearly always prefer the five free drawings in wash in Paris 54 to the ... finished and polished paintings in the same manuscript." I do not share this preference, although I have seen other Byzantine manuscripts where I do (e.g., the Vatican Job, Vat. gr. 751). J. Labarte, Histoire des arts industriels, 2nd ed. (Paris, 1875), 189, was critical of the general style of the miniatures but felt, unlike Willoughby, that the "coloring lacks less than the drawing."
} 
Cure of the Man with Dropsy, folio 233v

Visitation, folio 177v (Fig. 11)

Anointing, folio 203v (Fig. 15)

The first three miniatures have thin, red-ink rectangular frames, inside which the general features are sketched in a pale yellow wash (Fig. 12) ${ }^{67}$ The composition is sketched in fully enough to indicate where gold needed to be applied. The gold backgrounds and nimbi are also complete, with the exception of the nimbus in Christ Asleep in the Boat on folio $207 \mathrm{r}^{68}$ This exception makes readily visible the white gesso base upon which the artist applied his gold. ${ }^{69}$

The fourth miniature on the list, the Visitation (Fig. 11), shows the next stage of execution, in which brown ink was used to delineate more specific details of both figures and architecture. The facial features and the hair of the figures, as well as some of the folds of their garments are now indicated, as are the stairs, windows, and the archway of the building on the right side of the composition.

The fifth and most advanced of the unfinished miniatures, the Anointing of Christ's Feet (Fig. 15), is perhaps the most revealing. Here, the artist has reinforced most of the red-ink frame with a thicker line of red paint. Significant portions of the color have been applied. Apparently, the artist worked with one color at a time, painting all areas in the composition intended to be that color before moving on to the next hue. Several colors were completed in this fashion, including red, green, dark brown, and mustard. A dark ochre ground was applied to all of the faces, except that of the kneeling figure. Was this ochre the last color applied by the artist, and was he interrupted before applying it to the face of the kneeling figure? Not necessarily, since the kneeling figure is the only female depicted and women's faces may not have received the dark ochre ground. ${ }^{70}$

The evidence provided by these five miniatures indicates the following steps:

\footnotetext{
${ }^{67}$ Conversely, the line drawings of the manuscripts of the decorative style were executed in magenta. See Carr, Byzantine Illumination, 1150-1250, chap. 1, where she maintains that many of the members of this group were produced in Cyprus or Palestine. In an unusual deluxe member of the decorative style group, Malibu, J. Paul Getty Museum, Ludwig II 5 (olim Phillipps 3887), however, Buchthal notes that some of the miniatures show no evidence of underdrawing. See H. Buchthal, "An Unknown Byzantine Manuscript of the Thirteenth Century," Connoisseur 155 (1964): 221, and Carr, Byzantine Illumination, 1150-1250, 252-53.

${ }^{68}$ See J. J. G. Alexander, Medieval Illuminators and Their Methods of Work (New Haven-London, 1992), 40. M. P. Brown, Understanding Illuminated Manuscripts: A Guide to Technical Terms (Malibu, Calif., 1994), 59, writes "Gilding formed the first stage in the painting processes of illumination, since it was a messy activity, the gilded area often requiring trimming with a knife."

${ }^{69}$ The most thorough discussion of Paris 54's technique is found in H. Bordier, Descriptions des peintures et autres ornements contenus dans les manuscrits grecs de la Bibliothèque nationale (Paris, 1883), 228. He proposed that this gesso base was probably made up of a combination of albumen and starch. See "Goldgrund" $R B K$ 2:882-83. Millet, Recherches sur l'iconographie de l'Évangile, 7, notes that the gold of the marginal miniatures in Paris, Bibliothèque nationale, suppl. gr. 914 is painted over a plaster base. See also Tikkanen, Studien über die Farbengebung, 182. O. Demus, "Die Farbe in der byzantinischen Buchmalerei," Palette 26 (1967): 9-11 notes that most of the gold in Byzantine manuscripts was applied in powder form. See also Brown, Understanding Illuminated Manuscripts, 58-59, for the use of gesso in gilding.

${ }^{70}$ Der Nersessian, Miniature Painting in the Armenian Kingdom of Cilicia, 1:92, notes that in some of the miniatures of New Julfa, Monastery of the Holy Savior, 57/161, all but the facial features have been depicted. She assumed that they were to be completed by another artist.
} 
1. The scribe reserved space for the miniature and may or may not have drawn a rectangular frame in red ink. The frame was executed in one of the two red inks used in the multicolored text (Fig. 9).

2. The artist sketched the most general features of the composition in a pale yellow wash. The composition had to be sufficiently advanced so that all portions requiring gold could be determined (Fig. 12).

3. A thick white gesso base was applied to those areas designated to receive gold (background, nimbi, etc.).

4. Gold was applied.

5. The composition was further detailed with brown ink (Fig. 11).

6. The composition was filled in by applying one color at a time (Fig. 15).

A study of flaked areas in completed miniatures in Paris 54 indicates that not all narrative scenes were executed in this fashion, however. For example, it is difficult to confirm whether the gold of the miniatures of Matthew, Mark, and John is applied over the raised white gesso ground that is so apparent in the miniatures from Luke. In addition, flaked areas of completed miniatures of Matthew indicate that a variety of colors was used for the underdrawings. In the Nativity, a pale green color is visible beneath the flaked area on Joseph's chest, and, in the scene of the Holy Women at the Tomb, light mauve underpainting can be seen where the paint of the wall has flaked. The evidence provided by the Wedding Feast of the King's Son is probably the most striking-here, in the flaked areas of the architecture on the left side of the composition, a hot pink-orange hue was used to sketch the buildings. These variations suggest that several artists were responsible for the miniatures of Paris 54 but that the five unfinished miniatures of Luke are the work of one master.

The unfinished miniatures of the narrative cycle provide surprising parallels with the working methods utilized by the Latin scribe in folios $120 \mathrm{v}-141 \mathrm{v}$. The filling-in of the Latin text one color at a time is analogous to the way in which the artist responsible for the unfinished miniatures in Luke colored his miniatures (Fig. 8). Both methods probably reflect time-saving devices utilized by professionals.

\section{SumMARY AND CONCLUSIONS}

Text Figure 1 summarizes the status of Paris 54's Greek and Latin texts and the degree of completion of the narrative miniatures. Matthew's Gospel is the only one complete in all three categories. All evidence indicates that the Greek text was written before the corresponding Latin text. The scribe responsible for the Greek text apparently refined the initial concept of the varied ink colors as he proceeded. Our observations concerning the initial passages in blue ink on folios 13r-19r suggest this. This same scribe was responsible for reserving space throughout the manuscript for the narrative miniatures. This was accomplished by leaving a number of blank lines in the text, typically just before the relevant passage was to be written. Frequently these blank spaces were further defined by a frame drawn in one of the two red ink colors used for the text.

The evidence from Mark's Gospel indicates that the Latin text and narrative miniatures were produced simultaneously. The point at which the Latin text is taken over 
exclusively by the new hand using the inappropriate monochromatic black ink coincides exactly with the appearance of the first uninitiated miniature (Cure of the Man with the Dumb Spirit). Both occur on folio 142r, the first folio of the fourth quire of Mark (Fig. 9).

In Luke's Gospel, by contrast, the Latin text column is blank. Surprisingly, however, work on its narrative cycle was well advanced, with five completed miniatures, five unfinished miniatures, and ten uninitiated ones. Moreover, even though Luke's Latin text was not executed, there are notable parallels between textual and codicological anomalies and the location of Luke's unfinished miniatures. This is seen at the seventh quire of Luke beginning on folio 234. From here until the end of Luke, none of the miniatures was even begun. The Greek quire signatures disappear and a new system of lineation is introduced. Moreover, starting on folio 235, the canon numbers are suddenly placed in the right margin as opposed to the left for the folio rectos.

Finally, in John's Gospel, some fifty folios of the Latin text were completed by yet another, perhaps untrained hand in dark brown ink. Only one miniature, Christ and the Samaritan Woman at the Well, was executed. This is the third, not the first miniature in John, but it is the first miniature of the first quire devoted entirely to John's text.

The foregoing summary suggests that work on Paris 54 progressed in several phases. The first phase saw the completion of Matthew in all three major aspects: Greek text, Latin text, and narrative miniatures. This phase also saw the completion of all of Mark's Greek text. The first four miniatures of Mark (i.e., through fol. 125v) were also executed at this time and are attributed to Artist B, the same artistic personality responsible for the majority of the miniatures of Matthew. However, only that portion of Mark's Latin text written in polychromatic ink can be assigned to this phase.

I think that the Greek texts of Luke and John were also executed during the first phase. While another scribe may have written quire 23 (quire 7 of Luke), the fact that he worked in a style very similar to the primary Greek scribe and used the polychromatic ink colors suggests that, despite codicological inconsistencies from quire 23 through the beginning of John's Gospel, the Greek texts of Luke and John are likely to be products of the first phase.

The second phase may have followed quite quickly on the heels of the first, with only a brief lull between them. Phase Two had no impact on the texts but introduced a new artist, Artist C, who executed the five completed and five unfinished miniatures of Luke, as well as the one completed miniature in John's Gospel. The fact that Artist C did not attempt to execute the uninitiated miniatures of Mark suggests that Artist B was expected to return to finish his task.

It is more difficult to explain why work on the Latin text was allowed to lapse, even as Artist $\mathrm{C}$ worked on the miniatures of Luke and completed one in John. Was no Latin scribe available? This seems unlikely, since a number of scribes apparently participated in the polychromatic Latin texts of Matthew and Mark. ${ }^{71}$

A seemingly greater time gap separated Phase Two and Phase Three. Phase Three was limited to text additions in the inappropriate black ink found sporadically in folios $121 \mathrm{v}-141 \mathrm{v}$ of Mark's text and exclusively in folios 142r-150r. The fifty or so folios of

\footnotetext{
${ }^{71}$ Many complex paleographical issues are raised by the Latin scribes of Paris 54 and it would take a specialist to address them adequately.
} 
John's Latin text, executed in dark brown ink only from its beginning on folio $279 \mathrm{r}$ through folio 329r, may also date from this phase. The fact that these scribes never attempted to execute their texts in the polychromatic ink colors suggests that circumstances had changed so radically that the role originally envisioned for the manuscript was no longer relevant. Perhaps, the patron had died and resources become so limited that the only course available was to finish the manuscript as expeditiously as possible so that it could, at least, serve some purpose, if not precisely the one for which it was intended. Yet, even that was not accomplished, and Paris 54, for reasons we may never really comprehend, remained unfinished in its Latin text, its narrative miniatures, and its ornament.

Ironically, we have gained the least insight into the modus operandi of scribes and artists from the first Gospel of Paris 54. Matthew's Gospel, essentially complete in its text and miniatures, offers few clues concerning the process by which this manuscript was written and illustrated. It was, instead, the unfinished text and illustrations of the Gospels of Mark and Luke that revealed the most information about the way in which this work was produced. Codicological and textual anomalies in these two Gospels can be linked rather closely with similar disruptions in miniature production. Taken together, the evidence makes apparent that artists and scribes worked more intimately in the production of this manuscript than is generally recognized as common in the Byzantine sphere. 


\section{Appendix}

\section{Description of Contents of Paris, Bibliothèque Nationale de France, Cod. Gr. 54}

i, ii, iii, I Three unnumbered parchment folios (which I refer to as i, ii, iii) and a fourth labelled "I" precede folio 1.

Folios 1-10 These folios do not include any quire signatures. Folios 1-9r contain a Latin set of unornamented canon tables on the left side of each page. Space was reserved on the right for canon tables in Greek.

Quire 172 Folios 11r-20v, Matt. 1:1-5:12

Folio 10v, portrait of the Evangelist Matthew

Folio 11r, beginning of Matthew's text: missing headpiece and both initials at beginning of texts

Folio 13v, Nativity $(7.6 \times 17.2 \mathrm{~cm})$

Quire 2 Folios 21r-30v, Matt. 5:12-8:10

Quire 3 Folios 31r-40v, Matt. 8:10-11:1

Folio 32v, Exorcism of Demons $(7.1 \times 17.4 \mathrm{~cm})$

Folio 35v, Cure of the Woman with the Issue of Blood $(7.3 \times 17.3 \mathrm{~cm})$

Quire $4 \quad$ Folios 41r-50v, Matt. 11:1-13:31

Quire $5 \quad$ Folios 51r-60v, Matt. 13:31-16.9

Folio 55r, Miracle of the Loaves $(10.4 \times 17.1 \mathrm{~cm})$

Quire $6 \quad$ Folios 61r-70v, Matt. 16:9-19:9

Quire $7 \quad$ Folios 70r ${ }^{73}-79 v$, Matt. 19:10-22:1

${ }^{72}$ Greek quire signatures are found through quire 22. Armenian quire signatures are found throughout the manuscript.

${ }^{73} \mathrm{An}$ error was made during the pagination of the manuscript. There are two folios numbered 70 and no folio 71 . 
Quire $8 \quad$ Folios 80r-89v, Matt. 22:2-24:38

Folio 80r, Marriage Feast of the King's Son $(7.5 \times 17.3 \mathrm{~cm})$

Quire 9 Folios 90r-99v, Matt. 24:39-26:55

Folio $91 \mathrm{r}$, Wise and Foolish Virgins $(7.3 \times 17.4 \mathrm{~cm})$

Folio 96v, Last Supper $(9.5 \times 17.3 \mathrm{~cm})$

Folio 99r, Betrayal $(8.9 \times 17.1 \mathrm{~cm})$

Quire 10 Folios 100r-109v, Matt. 26:55-28:20

Folio 101r, Denial of Peter $(7.8 \times 17.2 \mathrm{~cm})$

Folio 102r, Remorse of Peter $(8.9 \times 17.2 \mathrm{~cm})$

Folio $107 \mathrm{r}$, Deposition $(7.7 \times 16.8 \mathrm{~cm})$

Folio 108r, Marys at the Sepulchre $(8.2 \times 17.4 \mathrm{~cm})$

Folio 109v, end of Matthew's text

Folios 110-111, bifolium insert

Folios 110r and 110v, blank

Folio $111 \mathrm{r}$, portrait of the Evangelist Mark

Folio 111v, blank

Quire $11 \quad$ Folios 112r-121v, Mark 1:1-4:5

Folio 112r, beginning of Mark's text: missing headpiece

Folio 114v, Peter's Mother-in-Law $(8.3 \times 17.5 \mathrm{~cm})$

Folio $115 \mathrm{v}$, Cure of the Leper $(7.7 \times 17 \mathrm{~cm})$

Folio 121r, end of perfect color parallelism of Latin text and first appearance of new Latin hand using inappropriate black ink for passages that should have been crimson

Quire 12 Folios 122r-131v, Mark 4:5-6:34

Folio $124 \mathrm{v}$, Christ Stilling the Water $(8.9 \times 17.4 \mathrm{~cm})$

Folio 125v, Exorcism of the Demoniac $(8.7 \times 16.8 \mathrm{~cm})$

Crimson Latin text by a new scribe

Quire 13 Folios 132r-141v, Mark 6:34-9:18

Folios 132r and 133r, evidence of new Latin hand using wrong color ink

Quire 14 Folios 142r-151v, Mark 9:18-11:29

Folio 142r, Cure of the Dumb Spirit (uninitiated; red-ink frame only)

Folios 142r-150r, Latin text exclusively in black ink by new Latin hand first

seen on folio $121 \mathrm{r}$

Folios 150v ff, no Latin text

Quire 15 Folios 152r-161v, Mark 11:29-14:25

No Latin text

Quire 16 Folios 162r-171v, Mark 14:25-16:14

Folio 162v, Gethsemane (uninitiated; space reserved)

Folio 166r, Denial of Peter (uninitiated; red-ink frame) 
Folio 167v, Mocking of Christ (uninitiated; red-ink frame)

Folio 168v, Crucifixion (uninitiated; space reserved)

No Latin text

Folio 172r, blank

Folio 172v, blank

Folio 173r, portrait of the Evangelist Luke (an insert)

Folio 173v, blank

Quire 17 Folios 174r-183v, Luke 1:1-2:44

Folio 174r, beginning of Luke's text: missing headpiece, rubrics, and initials

Folio $176 \mathrm{r}$, Annunciation $(7.9 \times 17.3 \mathrm{~cm})$

Folio $177 \mathrm{v}$, Visitation (unfinished) $(8.3 \times 17.1 \mathrm{~cm})$

Folio 182r, Presentation (unfinished) $(8.3 \times 17 \mathrm{~cm})$

No Latin text

Quire $18 \quad$ Folios 184r-193v, Luke 2:45-5:21

Folio 186v, Baptism $(8.7 \times 17.4 \mathrm{~cm})$

Folio 191v, Miraculous Draught of Fishes (uninitiated; red-ink frame)

Folio 193v, Cure of the Paralytic $(7.8 \times 17.3 \mathrm{~cm})$

No Latin text

Quire 19 Folios 194r-203v, Luke 5:21-7:39

Folio 201r, Son of Widow of Naim $(8.7 \times 17.5 \mathrm{~cm})$

Folio 203v, Anointing of Christ's Feet (unfinished) $(7.7 \times 17.1 \mathrm{~cm})$

Folio 194r, brief resumption of Latin text

Quire $20 \quad$ Folios 204r-213v, Luke 7:39-9:33

Folio 207r, Christ Asleep in the Boat (unfinished) $(8.2 \times 17 \mathrm{~cm})$

Folio 213r, Transfiguration $(10.2 \times 17.4 \mathrm{~cm})$

No Latin text

Quire $21 \quad$ Folios 214r-223v, Luke 9:33-11:41

No Latin text

Quire 22 Folios 224r-233v, Luke 11:41-14:1

Folio 233v, Cure of the Man with Dropsy (unfinished; red-ink frame)

No Latin text

Quire $23 \quad$ Folios 234r-243v, Luke 14:2-17:9

Folio 235v, Meal of the Rich Man (uninitiated; red-ink frame)

Folio 241v, Rich Man and Lazarus (uninitiated; red-ink frame)

No Latin text; Greek quire signatures cease

New lineation schema

Canon numbers for folio rectos now placed in far right margin (continues

through the end of Luke) 
Quire $24 \quad$ Folios 244r-253v, Luke 17:9-19:44

Folio 247r, unknown miniature subject/scribal error? (uninitiated; red-ink frame at bottom of the page measuring only $5.8 \times 16.9 \mathrm{~cm})$

Folio 247v, Parable of the Pharisee and the Publican (uninitiated; red-ink frame measuring $7.8 \times 17.2 \mathrm{~cm}$ )

Folio 248v, Parable of the Rich Man and Eternal Life (uninitiated; red-ink frame)

No Latin text; no Greek quire signature

Quire 25 Folios 254r-263v, Luke 19:44-22:28

Folio 255r, Parable of the Master of the Vineyard (uninitiated; red-ink frame)

Folio 258v, Parable of the Widow's Mite (uninitiated; red-ink frame)

No Latin text; no Greek quire signature

Quire 26 Folios 264r-273v, Luke 22:28-24:20

Folio 269v, Simon Carries the Cross (uninitiated; red-ink frame)

No Latin text; no Greek quire signature

Quire $27 \quad$ Folios 274r-284v, Luke 24:20-John 2:17

Folio 276v, Ascension (uninitiated; red-ink frame)

Folio 276v, end of Luke's Gospel

Folio 277r, kephalaia listing for Gospel of John

Folio $277 \mathrm{v}$, blank

Folio 278r, blank

Folio $278 \mathrm{v}$, portrait of the Evangelist John (an insert)

Folio 279r, beginning of John's Gospel: no headpiece or initials. Rubric for

Greek text only; resumption of the Latin text by a different hand in dark

brown ink

Folio 280r, Anastasis (uninitiated; red-ink frame)

Folio 283v, Wedding at Cana (uninitiated; red-ink frame)

No Greek quire signature

Quire 28 Folios 285r-294v, John 2:17-5:11

Folio 289r, Samaritan Woman at the Well $(7.5 \times 17 \mathrm{~cm})$

Folio 294r, Cure at the Pool (uninitiated; red-ink frame)

No Greek quire signature

Quire $29 \quad$ Folios 295r-304v, John 5:11-7:3

No Greek quire signature

Quire $30 \quad$ Folios 305r-314v, John 7:4-9:2

No canon numbers; no kephalaia

No Greek quire signature

Quire $31 \quad$ Folios 315r-324v, John 9:3-11:32

Folio 315r, Cure of the Man Born Blind (uninitiated; red-ink frame)

Folio 322, Raising of Lazarus (uninitiated; red-ink frame)

No Greek quire signature 


\section{PARIS, BIBLIOTHÈQUE NATIONALE DE FRANCE, CODEX GREC 54}

Quire 32 Folios 325r-334v, John 11:32-13:33

Folio 328r, Entry into Jerusalem (uninitiated; red-ink frame)

Folio 332v, Washing of the Feet (uninitiated; red-ink frame)

Folio 329r, Latin text stops

No Greek quire signature

Quire 33 Folios 335r-344v, John 13:33-17:12

Folios 335r-339v, no Latin text; no Greek quire signature

Quire $34 \quad$ Folios 345r-354v, John 17:12-19:41

No Latin text; no Greek quire signature

Quire 35 Folios 355r-364v, John 19:41-21:25 (end of John)

Folio 356r, Noli Me Tangere (uninitiated; red-ink frame)

Folio 357v, Doubting of Thomas (uninitiated; red-ink frame)

Folio 359v, Appearance to Disciples (uninitiated; red-ink frame)

No Latin text; no Greek quire signature 